\title{
Improving the performance of dairy cattle with a xylanase-rich exogenous enzyme preparation
}

\author{
J. J. Romero, ${ }^{* 1}$ E. G. Macias, $†$ Z. X. Ma, ${ }^{*}$ R. M. Martins, $\ddagger$ C. R. Staples, ${ }^{*}$ K. A. Beauchemin, $\S$ \\ and A. T. Adesogan*2 \\ *Department of Animal Sciences, Institute of Food and Agricultural Sciences, University of Florida, Gainesville 32608 \\ †Departamento de Zootecnia, Universidad Nacional Agraria La Molina, Lima, Lima 12, Peru \\ †Departamento de Zootecnia, Universidade Federal de Viçosa, Viçosa, 36570, Brazil \\ §Agriculture and Agri-Food Canada, Lethbridge Research Center, Lethbridge, AB T1J 4B1, Canada
}

\begin{abstract}
The objective of this experiment was to examine effects of adding 2 exogenous fibrolytic enzymes (EFE) to the total mixed ration (TMR) on the performance of lactating dairy cows (experiment 1) and the kinetics of ruminal degradation of the diet (experiment 2). Twelve EFE had been screened in a series of in vitro assays that identified the most potent EFE and their optimal doses for increasing the digestibility of bermudagrass. In experiment 1, 66 Holstein cows ( $21 \pm 5 \mathrm{~d}$ in milk) were grouped by previous milk production and parity (45 multiparous and 21 primiparous) and assigned randomly to 1 of the following 3 treatments: (1) control (CON, untreated), (2) Xylanase Plus $[2 \mathrm{~A}, 1 \mathrm{~mL} / \mathrm{kg}$ of TMR dry matter (DM); Dyadic International, Jupiter, FL], and (3) a 75:25 (vol/vol) mixture of Cellulase Plus and Xylanase Plus EFE (3A, $3.4 \mathrm{~mL} / \mathrm{kg}$ of TMR DM; Dyadic International). The EFE were sprayed twice daily onto a TMR (10\% bermudagrass silage, $35 \%$ corn silage, $5 \%$ alfalfa-orchardgrass hay mixture, and 50\% concentrates; DM basis) and fed for a 14-d training and covariate period and a $70-\mathrm{d}$ measurement period. Experiment 2 aimed to examine the in situ DM ruminal degradability and ruminal fermentation measurements of the diets fed in experiment 1 . Three ruminally fistulated lactating Holstein cows were assigned to the diets. The experiment had a $3 \times 3$ Latin square design with 23 -d periods. In experiment 1 , application of $2 \mathrm{~A}$ increased intakes $(\mathrm{kg} / \mathrm{d})$ of DM (23.5 vs. 22.6), organic matter (21.9 vs. 20.9 ), and crude protein (3.9 vs. 3.7 ) and tended to increase yields $(\mathrm{kg} / \mathrm{d})$ of fat-corrected milk (41.8 vs. 40.7$)$ and milk fat (1.48 vs. 1.44$)$. In particular, $2 \mathrm{~A}$ increased milk yield $(\mathrm{kg} / \mathrm{d})$ during wk 3
\end{abstract}

Received July 7, 2015.

Accepted December 30, 2015

${ }^{1}$ Current address: Department of Crop Science, North Carolina State University, 1104A Williams Hall, Raleigh, NC 27695-7620.

${ }^{2}$ Corresponding author: adesogan@ufl.edu
(41.2 vs. 39.8 , tendency), 6 (41.9 vs. 40.1 ), and 7 (42.1 vs. 40.4$)$, whereas $3 \mathrm{~A}$ increased milk yield $(\mathrm{kg} / \mathrm{d})$ during wk 6 (41.5 vs. 40.1, tendency), 8 (41.8 vs. 40.0 ), and 9 (40.9 vs. 39.5, tendency). In experiment 2, EFE treatment did not affect ruminal DM degradation kinetics or ruminal $\mathrm{pH}$, ammonia- $\mathrm{N}$, and volatile fatty acid concentration. Application of $2 \mathrm{~A}$ to the bermudagrassbased TMR increased DM intake and milk production, implying that this EFE could be used to increase the performance of lactating dairy cows fed diets containing up to $10 \%$ bermudagrass.

Key words: fibrolytic enzyme, dairy cattle, bermudagrass

\section{INTRODUCTION}

Several studies have examined the efficacy of using exogenous fibrolytic enzymes (EFE) to improve forage quality and ruminant animal performance but the results have been equivocal (Beauchemin et al., 2003; Adesogan et al., 2014; Meale et al., 2014). Supplementing EFE to nonruminant livestock can improve feed efficiency and allows for the inclusion of ingredients with a higher fiber concentration than corn (Bedford and Partridge, 2010). However, EFE use in ruminant diets has been limited due to inconsistent animal performance responses. This inconsistency is due partly to the wide array of conditions under which EFE are tested and the limited understanding of their mode of action (Beauchemin and Holtshausen, 2010). In most cases, enzymatic activities supplied by EFE are not novel to the rumen and therefore EFE act on the same plant cell wall targets as endogenous ruminal enzymes (Wang and McAllister, 2002). Consequently, EFE effects seem greater when the endogenous capacity of the rumen to digest fiber is decreased. This occurs in dairy cows in early lactation (Schingoethe et al., 1999; Knowlton et al., 2002), which typically have relatively low ruminal fiber digestion due to factors such as low ruminal $\mathrm{pH}$ and high total-tract rate of passage (Mouriño et al., 
2001; Cochran et al., 2007). Furthermore, EFE seem to be more effective at improving the productivity of cattle fed ad libitum relative to their effects on cattle fed for restricted intake (Yang et al., 2000; Beauchemin and Holtshausen, 2010), where the longer ruminal retention times result in more complete digestion of fiber.

Previous studies have examined effects of applying EFE to major forage crops such as corn silage and alfalfa and identified promising candidates for increasing in vitro NDF digestibility (NDFD; Eun and Beauchemin, 2007; Lynch et al., 2014). However, in tropical and subtropical regions such as the southeastern United States, perennial warm-season grasses are more agronomically and economically suited than alfalfa (Bernard et al., 2010) but their high fiber content and low digestibility limit dairy cow productivity (Hanna and Sollenberger, 2007). Consequently, such forages and the diets that include them are potentially good candidates for improvement by EFE. Arriola et al. (2011) reported that adding an EFE to a corn silage and alfalfa hay-based TMR for dairy cows increased NDF digestibility by $6 \%$, and increased feed efficiency (FCM:DMI) by about $16 \%$. However, when the same EFE (Queiroz et al., 2011) and another one (Bernard et al., 2010) were applied to a bermudagrass silage-based TMR, none of the performance measures was increased. Consequently, strategies that increase effectiveness of EFE at enhancing the digestion of bermudagrass and the performance of cows fed bermudagrass-based diets are needed. For this purpose, we developed a strategy to identify promising EFE candidates and the optimal conditions for their use. To choose the best EFE to test on a bermudagrassbased TMR for dairy cows, we conducted a series of in vitro experiments. The aims were to determine the most promising EFE for increasing the NDFD of bermudagrass haylage and its optimal dose, and to examine whether its efficacy would be improved by metal ion cofactors. These experiments (1) identified 5 of $12 \mathrm{EFE}$ that increased the NDFD of bermudagrass haylage by at least 8\% (Romero et al., 2015c), (2) determined the lowest doses of each of the 5 selected EFE that maximized the NDFD of bermudagrass haylage (Romero et al., 2015b), and (3) showed that metal ion cofactors such as manganese synergistically increased the effects some EFE on the NDFD of bermudagrass haylage but did not affect those of others (Romero et al., 2015a). These studies revealed that the most promising EFE for increasing the NDFD of bermudagrass haylage was EFE 2A (Xylanase Plus, Dyadic International, Jupiter, FL), and unlike others, its efficacy was not synergistically improved by adding cofactors. A final in vitro assay (Romero et al., 2014) validated the promise of EFE $2 \mathrm{~A}$ by showing that it was more effective at increasing the NDFD of corn silage, an alfalfa-orchardgrass hay mixture, or bermudagrass haylage than EFE 3A [75:25 (vol/vol) mixture of Cellulase Plus and Xylanase Plus, respectively, Dyadic International], which improved the feed efficiency of dairy cows (Arriola et al., 2011).

The objective of the present experiment was to examine effects of adding $2 \mathrm{EFE}(2 \mathrm{~A}$ or $3 \mathrm{~A}$ ) to a TMR containing bermudagrass haylage, corn silage, and an alfalfa-orchardgrass hay mixture, on DMI, ruminal fermentation, kinetics of ruminal digestion, and performance of lactating dairy cattle. We hypothesized that adding either of the EFE to the diet would increase the performance of cows, but EFE $2 \mathrm{~A}$ would produce a greater response because it increased the NDFD of the dietary forages to a greater extent than EFE 3A in the screening studies.

\section{MATERIALS AND METHODS}

\section{Location, Housing, and Weather}

The study was conducted at the University of Florida Dairy Unit (Hague) from February to August 2013 (26 wk). Cows were housed in a freestall, open-sided barn fitted with 2 rows of fans ( 1 fan $/ 6$ linear meters) for cooling. Fans were equipped with low-pressure water nozzles, and both fans and nozzles were activated once ambient temperature reached $21.1^{\circ} \mathrm{C}$. During the experiment, the mean temperature and relative humidity were $21.4^{\circ} \mathrm{C}$ and $80.9 \%$, with minima of $3.2^{\circ} \mathrm{C}$ and $49.0 \%$ and maxima of $28.3^{\circ} \mathrm{C}$ and $97.0 \%$, respectively (FAWN, 2013). Stalls $(1.14 \times 2.31 \times 1.21 \mathrm{~m})$ were bedded with sand for alleviation of hoof and leg stress. The areas between feed bunks and freestalls were flushed out twice daily by an automated flushing system.

\section{Animals and Treatments}

The University of Florida Institute of Food and Agricultural Sciences Animal Research Committee approved the protocol for this study. In experiment 1, 66 lactating Holstein cows in early lactation $(21 \pm 5$ DIM) were grouped by milk production $5 \mathrm{~d}$ before enrollment (16-20 \pm 5 DIM) and parity (45 multiparous and 21 primiparous). Cows were assigned randomly to 1 of the following 3 treatments: (1) Control (CON, untreated), (2) Xylanase Plus (2A, $1 \mathrm{~mL} / \mathrm{kg}$ of TMR DM), and (3) a 75:25 (vol/vol) mixture of Cellulase Plus and Xylanase Plus EFE (3A, $3.4 \mathrm{~mL} / \mathrm{kg}$ of TMR DM). The $3 \mathrm{~A}$ and $2 \mathrm{~A}$ EFE were called EFE $3 \mathrm{~A}$ and $2 \mathrm{~A}$, respectively, in the laboratory screening studies (Romero et al., $2015 \mathrm{~b}, \mathrm{c}$ ), and they were sourced from nonrecombinant Trichoderma reesei (Dyadic International). Commercial enzyme product names for crude extracts should be taken as proper nouns and not as specific Enzyme 
Table 1. Ingredient and chemical composition (mean \pm SD; \% of DM unless otherwise noted) of the Control diet used in the in situ and lactation studies

\begin{tabular}{lc}
\hline Item & Control \\
\hline Ingredient & \\
Corn silage & 35.1 \\
Corn grain & 20.6 \\
Soybean meal & 10.3 \\
Bermudagrass silage & 9.9 \\
Citrus pulp & 6.2 \\
Whole cottonseed & 5.2 \\
Alfalfa-orchardgrass hay & 5.0 \\
AminoPlus ${ }^{1}$ & 4.1 \\
Mineral mix & 3.7 \\
Chemical composition & \\
DM (\%) & 52.8 \\
OM & 93.9 \\
Ash & 6.7 \\
CP & 16.5 \\
NDF & 32.9 \\
ADF & 17.4 \\
Hemicellulose & 15.5 \\
NFC & 39.3 \\
NE & (Mcal/kg of DM) \\
\hline
\end{tabular}

${ }^{1} \mathrm{Ag}$ Processing Inc. (Omaha, NE).

${ }^{2}$ Mineral mix contained $26.4 \% \mathrm{CP}, 5.06 \% \mathrm{Ca}, 10.7 \% \mathrm{Na}, 6.8 \% \mathrm{~K}, 4.1 \%$ $\mathrm{Mg}, 0.26 \% \mathrm{~S}, 1.6 \% \mathrm{P}, 417 \mathrm{mg} / \mathrm{kg}$ of Mn, $665 \mathrm{mg} / \mathrm{kg}$ of Zn, $229 \mathrm{mg} /$ $\mathrm{kg}$ of $\mathrm{Cu}, 2,166 \mathrm{mg} / \mathrm{kg}$ of Fe, $24 \mathrm{mg} / \mathrm{kg}$ of Co, $14 \mathrm{mg} / \mathrm{kg}$ of I, $7.1 \mathrm{mg} /$ $\mathrm{kg}$ of Se, 116,511 IU of vitamin A/kg, and 1,164 IU of vitamin $\mathrm{E} / \mathrm{kg}$ (DM basis).

${ }^{3}$ Hemicellulose was calculated as the difference between NDF and ADF.

${ }^{4}$ Calculated as NFC $=100-[\mathrm{CP}+$ ash + fat $(\mathrm{NRC}, 2001$, values $)+$ $\mathrm{NDF}$.

Commission (EC) entries, as they contain several other activities (i.e., other EC numbers) that were not measured by the manufacturer.

Cows were fed the TMR at 0700 and $1300 \mathrm{~h}$ using separate $250-\mathrm{kg}$ capacity Calan Data Ranger systems (American Calan Inc., Northwood, NH) for each treatment. The EFE were diluted in deionized water (1:3 $\mathrm{vol} / \mathrm{vol}$ ) and sprayed with a handheld garden sprayer on the TMR while it was being mixed in the Data Ranger for 5 min. The TMR included $5.0 \%$ alfalfa-orchardgrass hay, $9.9 \%$ bermudagrass silage, and $35.1 \%$ corn silage (DM basis; Table 1), with NDF concentrations of 49.6 $\pm 3.5,65 \pm 2.2$, and $40.7 \pm 5.7 \%$ and CP concentrations of $12.0 \pm 1.3,13.0 \pm 2.2$, and $6.6 \pm 0.6 \%$, respectively. Experimental diets were formulated to meet
NRC (2001) guidelines for a dairy cow producing $40 \mathrm{~kg}$ of milk with milk fat and protein concentrations of 3.5 and $2.85 \%$, respectively. Water was provided ad libitum from an automatic watering system. Cows were fed ad libitum ( $115 \%$ of the previous day's intake) individually using Calan gates (American Calan Inc.). Cows were fed a common diet during the first $14 \mathrm{~d}$ of the experiment, and the last $11 \mathrm{~d}$ were considered the covariate period. This was followed by a 70-d measurement period during which cows were fed EFE-treated or untreated TMR. Ingredient samples were taken twice a week during the measurement period to determine DM concentrations $\left(48 \mathrm{~h}\right.$ at $60^{\circ} \mathrm{C}$ ) of the diets and the amounts of enzyme applied were adjusted weekly based on changes in the DM concentration of the silages.

\section{Enzymatic Activities}

Table 2 lists the key enzymatic activities and protein concentrations of the EFE. Endoglucanase (EC 3.2.1.4, endo- $\beta$-1,4-glucanase), exoglucanase (EC 3.2.1.91, exo$\beta-1,4$-glucanase), and xylanase (EC 3.2.1.8, endo- $\beta-1,4$ xylanase) activities were quantified using carboxymethylcellulose, Avicel (Sigma-Aldrich, St. Louis, MO), and oat-spelt xylan as substrates (Wood and Bhat, 1988). All activities were measured at a temperature of $39^{\circ} \mathrm{C}$ and a $\mathrm{pH}$ of 6 to mimic ruminal conditions in lactating dairy cows. Protein concentration was measured using the Bio-Rad Protein Assay with BSA as the standard (Bio-Rad Laboratories, Hercules, CA). Because of batch-to-batch variations, the endoglucanase, xylanase, and exoglucanase activities, and protein concentration of $2 \mathrm{~A}$ were $75,92,144$, and $83 \%$ and those of $3 \mathrm{~A}$ were $79,86,65$, and $110 \%$ of the respective values in the corresponding enzyme preparations evaluated by Romero et al. (2015c).

\section{Sampling and Analysis}

Cows were milked twice daily (0800 and $2000 \mathrm{~h}$ ) and milk production was recorded. Milk composition was analyzed by in-line AfiLab milk analyzers (S.A.E. Afikim, Kibbutz Afikim, Israel) at each milking. Body weight was recorded twice daily after each milking by

Table 2. Activities of endoglucanase, xylanase, exoglucanase, and $\beta$-glucosidase ( $\mu \mathrm{mol}$ of sugar released $/ \mathrm{min}$ per $\mathrm{mL}$ ) and protein concentrations $(\mathrm{mg} / \mathrm{mL}$ ) of the exogenous fibrolytic enzyme (EFE) preparations examined

\begin{tabular}{lcccc}
\hline $\mathrm{EFE}^{1}$ & Endoglucanase & Xylanase & Exoglucanase & Protein \\
\hline $2 \mathrm{~A}$ & 2,714 & 26,926 & 1.21 & 92.07 \\
$3 \mathrm{~A}$ & 2,087 & 8,791 & 1.65 & 79.65 \\
\hline \multicolumn{2}{l}{ 2A (Xylanase Plus) and 3A (75:25 mixture of Cellulase Plus and 2A) } & were supplied by Dyadic (Jupiter, FL) \\
from nonrecombinant Trichoderma reesei.
\end{tabular}


the AfiFarm software system (S.A.E. Afikim). Body condition was scored by the same pair of observers on a 1 to 5 scale (Wildman et al., 1982) at the beginning of the trial and weekly thereafter.

Samples of the corn silage, bermudagrass silage, alfalfa hay, concentrates, and orts were collected every 3 to $4 \mathrm{~d}$, and dried in duplicate at $60^{\circ} \mathrm{C}$ for $48 \mathrm{~h}$ in a forcedair oven. Dried residues were composited monthly and ground to pass the 1-mm screen of a Wiley mill (A. H. Thomas, Philadelphia, PA). Ground samples were analyzed for concentrations of DM $\left(105^{\circ} \mathrm{C}\right.$ for $\left.16 \mathrm{~h}\right)$ and ash $\left(600^{\circ} \mathrm{C}\right.$ in a muffle furnace for $\left.8 \mathrm{~h}\right)$. Concentrations of NDF (Van Soest et al., 1991) and ADF (AOAC International, 2000) were measured sequentially using an Ankom 200 Fiber Analyzer (Ankom Technologies, Macedon, NY). Heat-stable $\alpha$-amylase was used in the NDF assay with no sodium sulfite, and the results were expressed inclusive of residual ash. Hemicellulose (HEM) was calculated as the difference between NDF and ADF. Nitrogen concentration was determined by the Dumas combustion method (AOAC International, 2000) using a Vario MAX CN Macro Elemental Analyzer (Elementar Analysensysteme GmbH, Hanau, Germany) and $\mathrm{CP}$ was calculated as $\mathrm{N} \times 6.25$.

Gelatin capsules containing $10 \mathrm{~g}$ of $\mathrm{Cr}_{2} \mathrm{O}_{3}$ were administered orally via a balling gun twice daily at 0700 and $1900 \mathrm{~h}$ for 10 consecutive days between $\mathrm{d} 74$ and 84. Fecal grab samples were collected twice daily just before administration of the capsules on d 80 to 84 . Fecal samples from daily collections were dried to a constant weight at $60^{\circ} \mathrm{C}$ in a forced-air oven and ground to pass the 1-mm screen of a Wiley mill (A. H. Thomas). Samples of dried feces were composited across the 10 sampling times to obtain one fecal sample per cow, which was analyzed for $\mathrm{Cr}$ by inductively coupled plasma-atomic emission spectrometry (Martin et al., 1994) and for DM, OM, N, NDF, and ADF using the previously described methods. Apparent digestibility of DM, OM, CP, NDF, HEM, and ADF were calculated by the marker ratio technique (Schneider and Flatt, 1975).

Blood samples were collected weekly by coccygeal venipuncture into vacutainer tubes containing sodium heparin anticoagulant (BD Vacutainer, Becton Dickinson and Co., Franklin Lakes, NJ). The blood was centrifuged at $2,500 \times g$ for $20 \mathrm{~min}$ at $4^{\circ} \mathrm{C}$ and the plasma was frozen $\left(-20^{\circ} \mathrm{C}\right)$. A Technicon autoanalyzer (Technicon Instruments Corp., Chauncey, NY) was used to measure plasma glucose (Bran and Luebbe Industrial Method 339-19; Gochman and Schmitz, 1972) and BUN (Bran and Luebbe Industrial Method 339-01; Marsh et al., 1965).

\section{Rumen Degradation Kinetics and Fermentation Measures}

In experiment 2, 3 ruminally cannulated multiparous Holstein cows in mid lactation $(159 \pm 47$ DIM and $735 \pm 8 \mathrm{~kg}$ of $\mathrm{BW}$ ) were assigned to the 3 treatments used in experiment 1 . Experiment 2 had a $3 \times 3$ Latin square design with 23 -d periods. Each period had $18 \mathrm{~d}$ for adaptation to the diets followed by $3 \mathrm{~d}$ for measuring in situ ruminal degradability of the TMR, $1 \mathrm{~d}$ to rest the rumen, and $1 \mathrm{~d}$ for measuring indices of ruminal fermentation. Cows were housed under the same conditions described previously and fed their TMR at 0900 and $1400 \mathrm{~h}$. The in situ DM degradability of the TMR was determined in quadruplicate within cows consuming the same treatment in that period. Ingredients were sampled every 3 to $4 \mathrm{~d}$ and composited during each period. Composite samples were dried for $48 \mathrm{~h}$ at $60^{\circ} \mathrm{C}$, ground to pass through the 4 -mm screen of a Wiley mill, mixed to reconstitute the TMR, and weighed $(5 \mathrm{~g}$ of DM) into $10 \times 20 \mathrm{~cm}$ Ankom R1020 in situ bags (Ankom Technology). Then, $2.6 \mathrm{~mL}$ of a solution containing nanopure water $(\mathrm{CON})$ with or without the equivalent dose of EFE used in experiment 1 was applied to $5 \mathrm{~g}$ of dried TMR in each bag $24 \mathrm{~h}$ before placing the bags in the rumen. The bags were tied approximately $1 \mathrm{~cm}$ below the top end with rubber bands and kept at $25^{\circ} \mathrm{C}$ during the 24 -h preincubation period. The bag pore size was $50 \mu \mathrm{m}$ and the ratio of sample size to free bag surface area was $12.5 \mathrm{mg} / \mathrm{cm}^{2}$. Bags were attached to a rope with clips, placed in the ventral sac of the rumen for $0,4,8,16,24,48$, and 72 $\mathrm{h}$, and removed simultaneously. Upon removal from the rumen, bags were washed with cold water manually to remove adherent feed particles and bacteria and then washed in a commercial washing machine (Kenmore, Benton Harbor, MI) using a cool wash cycle without soap. Washed bags were dried for $48 \mathrm{~h}$ at $60^{\circ} \mathrm{C}$ and hot-weighed. The model of Mertens (1977) was fitted to the DM degradation data using the NLIN procedure of SAS, version 9.4 (SAS Inst., Inc., Cary, NC). The model is of the form

$$
\mathrm{R}_{(\mathrm{t})}=\mathrm{D}_{\mathrm{i}} \times\left[\mathrm{e}^{-\mathrm{k}_{\mathrm{d}} \times(\mathrm{t}-\mathrm{L})}\right]+\mathrm{I}_{\mathrm{o}},
$$

where $\mathrm{R}_{(\mathrm{t})}=$ total undegraded residue at time $\mathrm{t}$ (\% of $\mathrm{DM}), \mathrm{D}_{\mathrm{i}}=$ potentially degradable fraction $(\%$ of $\mathrm{DM})$, $\mathrm{k}_{\mathrm{d}}=$ fractional rate of degradation of $\mathrm{D}_{\mathrm{i}}(\% / \mathrm{h}), \mathrm{t}=$ time (hours) incubated in the rumen, $\mathrm{L}=$ discrete lag time (hours), and $\mathrm{I}_{\mathrm{o}}=$ undegradable fraction after 72 $\mathrm{h}$ of incubation (\% of DM). The washout fraction = $100-\mathrm{D}_{\mathrm{i}}-\mathrm{I}_{\mathrm{o}}$. 
Samples of ruminal fluid $(200 \mathrm{~mL})$ were taken through the cannula from different locations in the rumen by aspiration at $0850 \mathrm{~h}$ (just before feeding) and every other hour thereafter until $1850 \mathrm{~h}$ on d 23 , for a total of 6 samples per treatment. The samples were immediately filtered with 2 layers of cheesecloth and analyzed for $\mathrm{pH}$ using an Accumet XL25 calibrated $\mathrm{pH}$ meter (Fisher Scientific, Pittsburgh, PA). Subsequently, the ruminal fluid $(13 \mathrm{~mL})$ was acidified with $130 \mu \mathrm{L}$ of $9.0 \mathrm{M} \mathrm{H}_{2} \mathrm{SO}_{4}$ and frozen at $-40^{\circ} \mathrm{C}$ for further analysis. Thawed samples were centrifuged at $8,000 \times g$ for 20 min at $4^{\circ} \mathrm{C}$ and the supernatant was analyzed for VFA and lactate (Muck and Dickerson, 1988) using a Merck Hitachi Elite LaChrome HPLC system (L2400, Hitachi, Tokyo, Japan) and a Bio-Rad Aminex HPX-87H column (Bio-Rad Laboratories). Ammonia-N concentration was measured using an adaptation of the Noel and Hambleton (1976) procedure that involves colorimetric $\mathrm{N}$ quantification on a Technicon Auto Analyzer (Technicon, Tarrytown, NY).

\section{Statistical Analysis}

A completely randomized design was used to analyze the weekly data from experiment 1 . The model used to analyze animal performance data was

$$
\begin{aligned}
Y_{i j k l}=\mu+ & T_{i}+P_{j}+T P_{i j}+C\left(_{i j}\right)_{k}+W_{l}+T W_{i l} \\
& +P W_{j l}+T P W_{i j l}+E_{i j k l},
\end{aligned}
$$

where $Y_{i j k l}=$ dependent variable, $\mu=$ general mean, $T_{i}$ $=$ fixed effect of EFE $i, P_{j}=$ fixed effect of parity $j, T P_{i j}$ $=$ fixed effect of the EFE $i \times$ parity $j$ interaction, $C\left({ }_{i j}\right)_{k}$ $=$ random effect of cow $k$ nested within treatment and parity $(k=1,2,3, \ldots, n), W_{l}=$ fixed effect of week $l$, $T W_{i l}=$ fixed effect of the EFE $i \times$ week $l$ interaction, $P W_{j l}=$ fixed effect of the parity $j \times$ week $l$ interaction, $T P W_{i j l}=$ fixed effect of the EFE $i \times$ parity $j \times$ week $l$ interaction, and $E_{i j k l}=$ experimental error.

The GLIMMIX procedure of SAS version 9.4 (SAS Inst. Inc., Cary, NC) was used to analyze the data. For the response variables involving repeated measures, the covariance structure with the smallest value for the Bayesian information criterion was selected, except when they had similar values, in which case the simpler model was chosen (Littell et al., 2006). For all cases, the autoregressive order $1[\mathrm{AR}(1)]$ covariance structure was selected. Milk production and DMI during the last $11 \mathrm{~d}$ of the training period were used as a covariate for analyzing the milk production and intake data, respectively.
A Latin square design was used to analyze the data from experiment 2 . The model used to analyze ruminal fermentation data was

$$
Y_{i j k l}=\mu+T_{i}+M_{j}+T M_{i j}+C_{k}+P_{l}+E_{i j k l},
$$

where $Y_{i j k l}=$ dependent variable, $\mu=$ general mean, $T_{i}=$ fixed effect of EFE $i, M_{j}=$ fixed effect of time $j$ (repeated measure), $T M_{i j}=$ fixed effect of the EFE $i \times$ time $j$ interaction, $C_{k}=$ random effect of cow $k, P_{l}=$ fixed effect of period $l$, and $E_{i j k l}=$ experimental error.

To analyze the ruminal degradation kinetics, the effect of time and interactions with time were excluded from the model. The autoregressive $[\mathrm{AR}(1)]$ covariance structure was used to adjust for all repeated measurements. Fisher's F-protected least significance difference test was used for mean separation. Treatment significance was declared at $P \leq 0.05$ and tendencies were declared at $P>0.05 \leq 0.1$.

\section{RESULTS AND DISCUSSION}

In experiment 1 , multiparous cows had greater $(P$ $<0.05$ ) voluntary intake of DM (DMI, 23.6 vs. $22.1 \pm$ $0.28 \mathrm{~kg} / \mathrm{d}), \mathrm{OM}$ (OMI, 22.0 vs. $20.6 \pm 0.26 \mathrm{~kg} / \mathrm{d}), \mathrm{CP}$ (CPI, 3.9 vs. $3.6 \pm 0.05 \mathrm{~kg} / \mathrm{d}$ ), NDF (NDFI, 7.5 vs. 7.0 $\pm 0.12 \mathrm{~kg} / \mathrm{d}$ ), HEM (HEMI, 3.5 vs. $3.3 \pm 0.06 \mathrm{~kg} / \mathrm{d}$ ), and $\mathrm{ADF}$ (ADFI, 3.9 vs. $3.7 \pm 0.07 \mathrm{~kg} / \mathrm{d}$ ), greater intake of digestible DM (17.3 vs. $15.0 \pm 0.30)$ and HEM $(2.3$ vs. $2.1 \pm 0.06 \mathrm{~kg} / \mathrm{d})$, lower digestibility of $\mathrm{OM}$ (OMD, 72.7 vs. $74.2 \pm 0.62 \%$ ), NDF (NDFD, 52.2 vs. $56.1 \pm 1.28 \%$ ), $\mathrm{ADF}$ (ADFD, 46.7 vs. $51.8 \pm 1.59 \%$ ), and lower blood glucose concentrations (64.0 vs. 65.5 $\pm 0.49 \mathrm{mg} / \mathrm{dL}$ ) than primiparous cows. No parity $\times$ treatment or parity $\times$ treatment $\times$ week interactions were detected $(P>0.1)$. Parity did not affect $3.5 \%$ FCM yield $(41.2 \pm 0.52 \mathrm{~kg} / \mathrm{d} ; P=0.91)$ or $\mathrm{BW}(601 \pm$ $3.9 \mathrm{~kg} ; P=0.69)$ of the cows.

On average, the cows in this study had similar DMI $(22.9 \pm 0.31 \mathrm{~kg} / \mathrm{d})$ to those in previous studies that evaluated EFE effects on diets containing bermudagrass, such as Bernard et al. (2010; $24.5 \mathrm{~kg} / \mathrm{d}$ ), Queiroz et al. (2011; $22.0 \mathrm{~kg} / \mathrm{d}$ ), and Dean et al. (2013; 21.3 $\mathrm{kg} / \mathrm{d}$ ). Across treatments, DMI increased continuously from wk 1 (20.8) until it reached a plateau at wk 8 to $10(24.1 \pm 0.25 \mathrm{~kg} / \mathrm{d}$; wk, $P<0.001$; data not shown). Compared with feeding CON and $3 \mathrm{~A}$, feeding $2 \mathrm{~A}$ increased mean DMI (23.5 vs. 22.6 and $22.5 \pm 0.31 \mathrm{~kg} / \mathrm{d}$; $P=0.039)$, OMI (21.9 vs. 20.9 and $21.0 \pm 0.28 \mathrm{~kg} / \mathrm{d}$; $P=0.023)$, and CPI (3.9 vs. 3.7 and $3.7 \pm 0.05 \mathrm{~kg} / \mathrm{d}$; $P=0.026)$, respectively, but feeding $3 \mathrm{~A}$ did not affect $(P>0.10)$ any measure of intake (Table 3$)$. Arriola et 
al. (2011) reported that applying the same 3A EFE to corn silage and alfalfa hay-based diets containing 33 or $48 \%$ concentrate had no effect on DMI, CPI, NDFI, or ADFI by cows in early lactation cows. We hypothesize that feeding $2 \mathrm{~A}$ instead of $3 \mathrm{~A}$ could have increased DMI in this study because of its greater xylanase to endoglucanase plus exoglucanase activity ratio (9.9 vs. 4.2) and the relatively high HEM concentration of the TMR relative to that used by Arriola et al. (2011). The 2A EFE also had degraded HEM effectively in previous experiments (Romero et al., 2015b,c). Greater DMI is beneficial for dairy cows because milk production is limited by intake of digestible energy (Beauchemin and Holtshausen, 2010). Dietary addition of EFE also has increased the DMI of corn silage-alfalfa hay (Dhiman et al., 2002) and barley-alfalfa silage based (Beauchemin et al., 2000) TMR in early- and mid-lactation cows, respectively. Furthermore, Lewis et al. (1999) reported that the DMI of cows in early lactation was increased by applying any of 3 doses of a T. reesei enzyme (Cornzyme, Finnfeeds Int., Marlborough, UK) to the dietary alfalfa hay and silage.

Enzyme EFE 3A was applied at 3.4 times the dose of $2 \mathrm{~A}$ and it provided much more endoglucanase and exoglucanase than $2 \mathrm{~A}$ when applied to the TMR. However, unlike 2A, 3A did not improve DMI. This could be because $3 \mathrm{~A}$ provided only $85 \%$ of the xylanase in $2 \mathrm{~A}$ when applied to the TMR, as well as the substantial difference in the ratio of xylanase to endoglucanase plus exoglucanase activities in both EFE. Previous in vitro experiments with bermudagrass (Romero et al., 2015c) showed that $3 \mathrm{~A}$ was effective at improving NDFD, but each of the component enzymes of $3 \mathrm{~A}$ ( $1 \mathrm{~A}$ and $2 \mathrm{~A}$ ) was more effective at increasing the in vitro NDFD of bermudagrass haylage than $3 \mathrm{~A}$, with $2 \mathrm{~A}$ being the most effective component. Eun and Beauchemin (2007) found that an earlier batch of $3 \mathrm{~A}$ (called $\mathrm{FF}+\mathrm{FT}$ ) improved the in vitro NDFD of corn silage and alfalfa hay when applied at $1 \mathrm{~g} / \mathrm{kg}$ of DM. That batch of $3 \mathrm{~A}$ had $75 \%$ of the endoglucanase activity and 10.2 times the protein concentration of the $3 \mathrm{~A}$ tested in this study. Phakachoed et al. (2013) showed that another batch of $3 \mathrm{~A}$ increased in vitro NDFD of corn silage when applied at $4 \mathrm{~mL} / \mathrm{kg}$ of DM. That batch of $3 \mathrm{~A}$ had lower xylanase $(20 \%)$ and endoglucanase $(16 \%)$ and higher exoglucanase $(842 \%)$ activities than those present in the batch used in this current study. These studies confirm that $3 \mathrm{~A}$ can be used to increase the in vitro NDFD of various forages but they also reveal notable batch-to-batch variations in the activity of the enzymes in $3 \mathrm{~A}$, even when measured with the same procedure (Colombatto and Beauchemin, 2003). Such batch-tobatch variations in enzyme activity may be due to variations in Trichoderma reesei culture conditions and crude extract processing (Considine and Coughlan, 1989; Paloheimo et al., 2010). Although such variations should be minimized, it should be noted that enzymatic activities are unreliable descriptors or predictors of the

Table 3. Effect of addition of fibrolytic enzymes to the diet on intake and digestibility by lactating dairy cows (experiment 1)

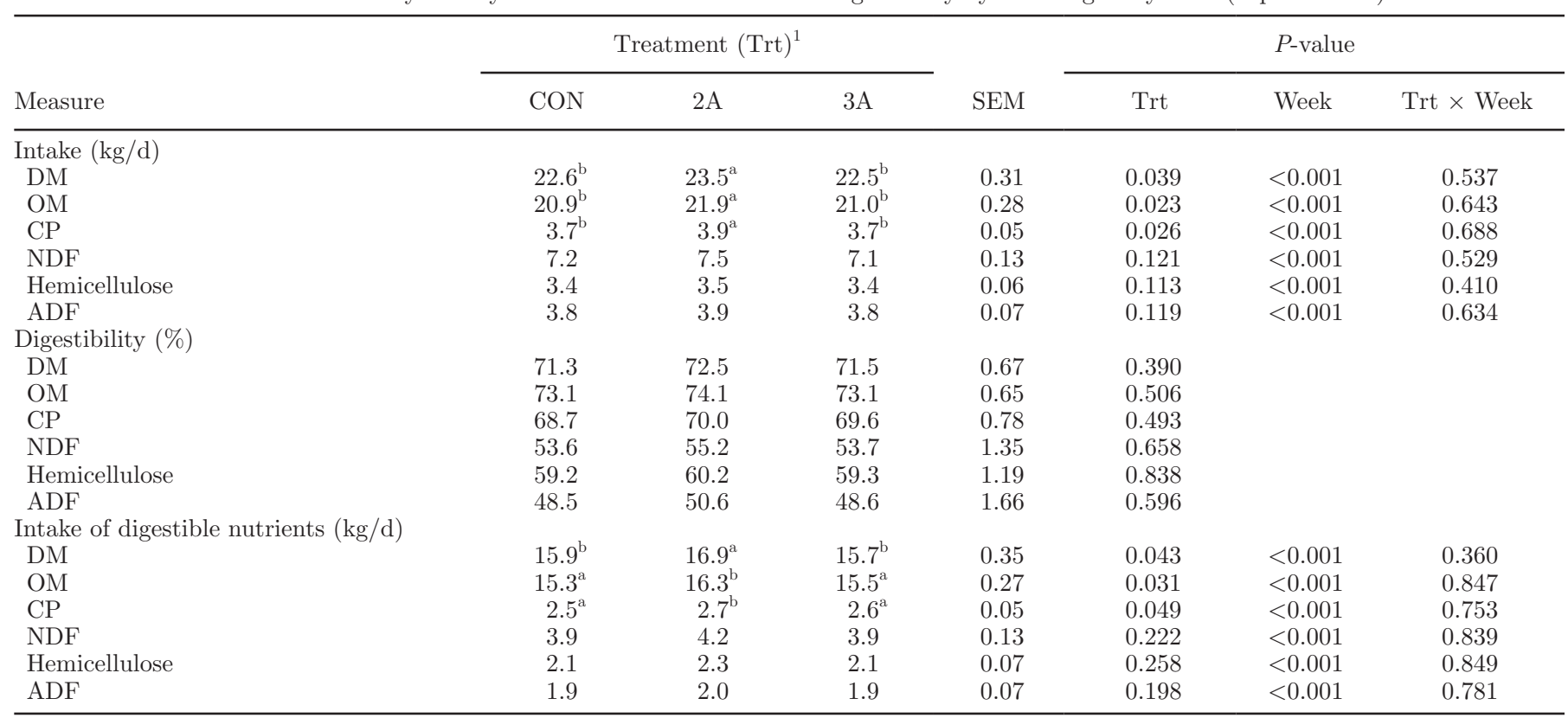

\footnotetext{
${ }^{a, b}$ Means in the same row with different superscripts differed $(P<0.05)$.
}

${ }^{1} \mathrm{CON}=$ control; $2 \mathrm{~A}=$ Xylanase Plus; $3 \mathrm{~A}=75: 25$ mixture of Cellulase Plus and 2A. Xylanase Plus and Cellulase Plus were produced by Dyadic (Jupiter, FL) from nonrecombinant Trichoderma reesei. 
capacity of an enzyme product to improve the in vitro digestibility of forages (Eun and Beauchemin, 2008; Romero et al., 2015c).

No effects on DMI of lactating dairy cows were reported when a similar $3 \mathrm{~A}$ preparation was applied at a slightly lower dose $(2.8 \mathrm{~mL} / \mathrm{kg})$ to a TMR containing $22 \% 4$ - or 7 -wk regrowth of bermudagrass silage (Queiroz et al., 2011). Similarly, Bernard et al. (2010) reported that adding an EFE from T. reesei (Promote NET, Cargill, Minnetonka, MN) to a TMR consisting of basal alfalfa or bermudagrass silage (12\% of TMR) had no effect on DMI. Dean et al. (2013) reported no increase in DMI of mid-lactation cows when the same Promote enzyme was applied at ensiling or at feeding to diets containing $35 \%$ of bermudagrass silage (DM basis). Therefore, enzymes have not improved the DMI of dairy cattle fed diets containing moderate to high levels of bermudagrass. The increased DMI observed in this study may be attributable to the high xylanolytic capacity of $2 \mathrm{~A}$, which is reflected by its high xylanase activity, high xylanase to endoglucanase plus exoglucanase ratio (9.9:1), and its consequent ability to hydrolyze bermudagrass cell walls and the HEM concentration of the TMR used in this trial. The 2A EFE increased the hydrolysis of bermudagrass cell walls into xylose by $21,400 \%$ compared with the $1,700 \%$ increase obtained with an equal dose of 3A (Romero et al., 2015c).

Digestibility measures were not affected by diet $(P>$ 0.39). Dean et al. (2013) reported no effect on DMD, NDFD, and CPD when the Promote EFE was applied to a bermudagrass-based TMR. Arriola et al. (2011) reported increases in DMD, NDFD, ADFD, and $\mathrm{CP}$ digestibility when $3 \mathrm{~A}$ EFE was applied to a corn silagebased TMR. The increased intake observed in the present study may have prevented an increase in total-tract digestibility due to a reduction in total-tract retention time and an increased rate of passage (Mertens, 1987; Allen, 1996; NRC, 2001). However, compared with $\mathrm{CON}$ and $3 \mathrm{~A}$, application of $2 \mathrm{~A}$ increased the intake of digestible DM (16.9 vs. 15.9 and $15.7 \mathrm{~kg} / \mathrm{d} ; P=$ $0.043), \mathrm{OM}(16.3$ vs. 15.3 and $15.5 \mathrm{~kg} / \mathrm{d} ; P=0.031$ ), and CP (2.7 vs. 2.5 and $2.6 \mathrm{~kg} / \mathrm{d} ; P=0.049)$ because it increased the corresponding intakes without affecting digestibilities. Across treatments, digestible DM intake increased from wk 1 (14.6) until it plateaued at wk 8 to $10(17.0 \pm 0.25 \mathrm{~kg} / \mathrm{d}$; wk; $P<0.001$; data not shown). Mean milk yield $(40.7 \pm 0.46 \mathrm{~kg} / \mathrm{d}$; Table 4$)$ was similar to that of Bernard et al. (2010; $41.4 \mathrm{~kg} / \mathrm{d})$ and greater than that reported by Queiroz et al. (2011; 38.4 $\mathrm{kg} / \mathrm{d})$ and Dean et al. (2013; $32.0 \mathrm{~kg} / \mathrm{d})$. These differences are due to variations in diet composition, environmental factors, and the BW and lactation stages of the cows in the studies. Cows fed $2 \mathrm{~A}$ had $(P<0.05)$ or tended to have $(P<0.1)$ greater milk yield than those fed the CON diet during wk 3,6 , and 7 , and those fed $3 \mathrm{~A}$ had greater milk yield than CON cows during wk 6,8 , and 9 (Figure 1; treatment $\times$ week interaction, $P$ $=0.04)$. Over the entire feeding period, application of EFE also tended to increase $3.5 \%$ FCM yield $(P=0.09$; $40.7,41.8$, and $41.0 \pm 0.38 \mathrm{~kg} / \mathrm{d}$ for $\mathrm{CON}, 2 \mathrm{~A}$, and $3 \mathrm{~A}$, respectively; Table 4) and numerically increased mean yields of milk $(P=0.15 ; 40.0,41.2$, and $40.8 \pm 0.46$ $\mathrm{kg} / \mathrm{d}$ for CON, $2 \mathrm{~A}$, and $3 \mathrm{~A}$, respectively). Across treatments, FCM yield was similar from wk 1 (41.2) to wk 7 (41.6), and then decreased until wk $10(40.0 \pm 0.33$ $\mathrm{kg} / \mathrm{d}$; week, $P<0.001$; data not shown). The changes in DMI and FCM production over time are typical of the changes in these response variables from 35 to 105 DIM in herds containing multiparous and primiparous cows (NRC, 2001). The increase in $3.5 \%$ FCM by $2 \mathrm{~A}$ is attributable to the increases in intakes and digestible intakes of DM, OM, and CP. However, the reason why $3 \mathrm{~A}$ increased $3.5 \% \mathrm{FCM}$ is unclear. Application of Promote (Bioavance Technologies Inc., Omaha, NE; Yang et al., 1999) and an experimental EFE (Finnfeeds Int.; Schingoethe et al., 1999) to alfalfa hay and corn silage increased the milk yield of cows in mid lactation (25.6 vs. $23.7 \mathrm{~kg} / \mathrm{d}$ ) and early lactation (27.3 vs. $25.4 \mathrm{~kg} / \mathrm{d}$ of $\mathrm{FCM}$ ), respectively. In the latter study, the responses occurred after 4 wk of feeding and were maintained for $8 \mathrm{wk}$. In the current study, increases in milk production due to feeding $2 \mathrm{~A}$ were evident after 3 wk of feeding and persisted until wk 7, although the differences at wh 4 and 5 were numerical $(P=0.11$ and 0.34 , respectively). Increases in milk production due to feeding $3 \mathrm{~A}$ were evident $(P<0.01)$ during wk 6 to 9 , except for wk $7(P=0.30$; Figure 1$)$. The reasons behind the delayed response of $3 \mathrm{~A}$ compared with $2 \mathrm{~A}$ are unclear. Nevertheless, data from both EFE indicate that, depending on the EFE, beneficial responses of feeding EFE may not be evident for 3 to $6 \mathrm{wk}$ after initiating the feeding of EFE.

Cows fed $2 \mathrm{~A}$ produced $2.8 \%$ more $(P=0.07$, tendency) milk fat $(\mathrm{kg} / \mathrm{d})$ than those fed the CON or 3A diets, which had similar milk fat yields (Table 4). The effect of treatment on milk lactose concentrations tended (treatment $\times$ week interaction, $P=0.10$ ) to differ with time, but treatments did not affect lactose concentration. Applying EFE had no other effects on milk component concentrations, milk protein or lactose yield, feed efficiency, BW, BW change, or BCS. Bernard et al. (2010) and Queiroz et al. (2011) reported no change in the milk yield, yield or composition of milk components, feed efficiency, or BW change due to application of EFE to bermudagrass-based diets. However, Dean et al. (2013) detected trends for increased milk fat and protein concentration and decreased feed efficiency when an EFE was applied to a TMR contain- 


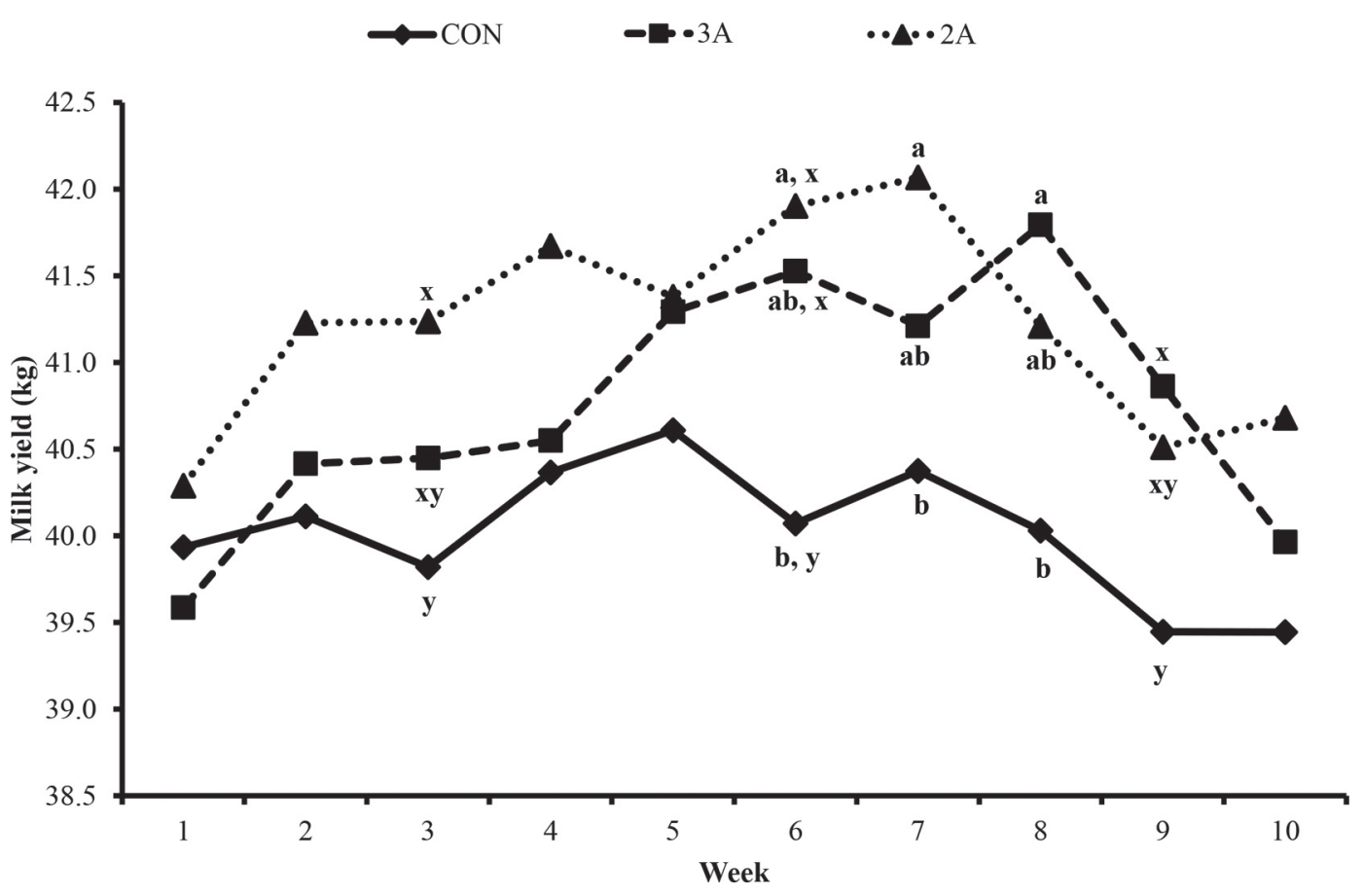

Figure 1. Effect of dietary treatment with fibrolytic enzymes on milk yield of lactating dairy cows (treatment $\times$ week, $P=0.035 ;$ SEM $=$ $0.59 \mathrm{~kg} / \mathrm{d}$ for week 1-10); means with different letters at the same wk differed at $P<0.05(\mathrm{a}, \mathrm{b})$ and $0.10(\mathrm{x}, \mathrm{y})$. CON $=$ control (untreated TMR); $3 \mathrm{~A}=\mathrm{TMR}$ treated with enzyme mixture (75:25 mixture of Cellulase Plus and 2A); and 2A = TMR treated with Xylanase Plus enzyme. Cows were at 35+ DIM during week 1. Xylanase Plus and Cellulase Plus were produced by Dyadic (Jupiter, FL) from nonrecombinant Trichoderma reesei.

ing $35 \%$ bermudagrass. Applying EFE to the alfalfa hay-corn silage-based TMR of Arriola et al. (2011) and the barley-alfalfa silage-based TMR of Holtshausen et al. (2011) increased feed efficiency but did not affect milk yield or composition. Treatment with EFE decreased DMI in the study of Holtshausen et al. (2011) but had no effect on DMI in that of Arriola et al. (2011). That the 2A treatment increased DMI and milk production in this study but not in those of Arriola et al. (2011) and Holtshausen et al. (2011) may have been due to the greater xylanase activity of $2 \mathrm{~A}(26,926$ vs. 3,630 and $2,604 \mu \mathrm{mol} / \mathrm{min}$ per $\mathrm{mL}$, respectively)

Table 4. Effect of dietary treatment with fibrolytic enzymes on milk yield, feed efficiency, yield and composition of milk fat, protein, and lactose, SCC, BW, BCS, and plasma metabolites of lactating dairy cows (experiment 1)

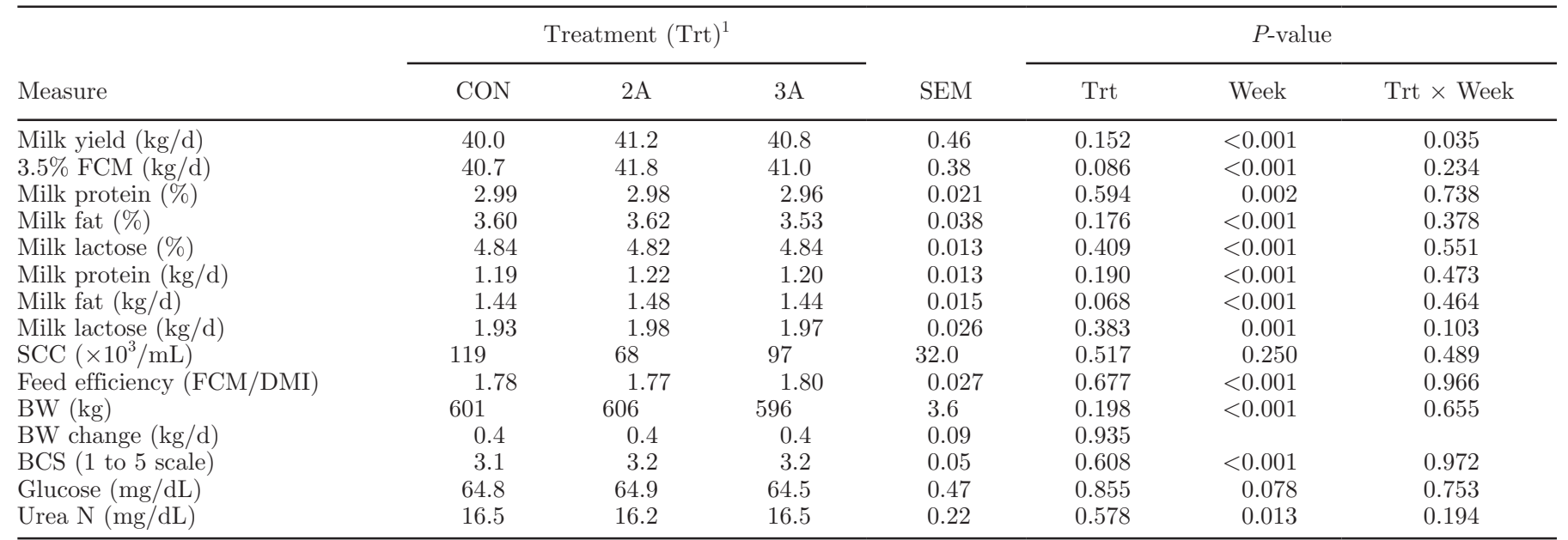

${ }^{1} \mathrm{CON}=$ control; $2 \mathrm{~A}=$ Xylanase Plus; $3 \mathrm{~A}=75: 25$ mixture of Cellulase Plus and 2A. Xylanase Plus and Cellulase Plus were produced by Dyadic (Jupiter, FL) from nonrecombinant Trichoderma reesei. 
and the greater HEM concentration of the diet used in this study compared with the other studies (15.5 vs. 11.9 and $10 \%$, respectively). This likely increased fiber hydrolysis by $2 \mathrm{~A}$, which would have reduced rumen fill and enhanced DMI and thereby increased the supply of nutrients required for milk production (Beauchemin and Holtshausen, 2010). This increase in DMI due to feeding 2A coupled with the corresponding increase in milk yield explains why $2 \mathrm{~A}$ did not increase feed efficiency. No EFE effects on plasma glucose and BUN concentrations were detected in this study or in the studies of Holtshausen et al. (2011) or Dean et al. (2013) or on the high-concentrate $(48 \%)$ diet of Arriola et al. (2011), which had a comparable concentrate level to those in the latter studies.

In experiment 2, no EFE effects were detected on the lag phase before in situ degradation of the TMR, the washout fraction, potentially degradable fraction, undegradable fraction, or fractional degradation rate of DM (Table 5). Similarly, no EFE effects on these response variables were reported due to applying EFE to different TMR (Arriola et al., 2011; Holtshausen et al., 2011), to different fractions of the diet (Dean et al., 2013), or to bermudagrass hay (Krueger et al., 2008; Romero et al., 2013).

Application of $2 \mathrm{~A}$ numerically reduced $(P=0.13)$ the concentration of ruminal acetate and did not affect concentrations of ammonia-N, total VFA, propionate, butyrate, isobutyrate, isovalerate, valerate; the acetate:propionate $(\mathbf{A}: \mathbf{P})$ and acetate plus butyrate:propionate ratios; or ruminal $\mathrm{pH}$ (Table 6). Molar proportions of individual VFA were also unaffected by treatment $(P>0.26$; data not shown). Previous in vitro studies (Romero et al., 2015b,c) revealed increased total VFA and propionate concentrations and a decreased $\mathrm{A}: \mathrm{P}$ when $2 \mathrm{~A}$ was applied to bermudagrass haylage, whereas $3 \mathrm{~A}$ did not affect these response variables. The lack of a similar response in this study for 2A may be attributable, at least partly, to application of $2 \mathrm{~A}$ to the TMR in this study versus to bermudag- rass haylage in the in vitro studies. Many studies have reported that dietary EFE treatment had no effect on total VFA concentration (Yang et al., 1999; Kung et al., 2002; Sutton et al., 2003). However, Arriola et al. (2011) reported that application of $3 \mathrm{~A}$ increased total VFA concentration and decreased A:P in ruminal fluid of lactating dairy cows. In that study, the total VFA concentrations for the control and enzyme-treated TMR containing a level of concentrates (48\%) similar to that in this study were 118.6 and $133.1 \mathrm{mM}$ and A:P were 2.94 and 2.59 , respectively. The comparatively greater total VFA concentration $(156 \pm 6.66 \mathrm{mM})$ and the lower A:P $(2.5 \pm 0.11)$ in the present study are likely attributable to differences in DMI and the compositions of the diets and EFE in the studies.

\section{CONCLUSIONS}

Application of 2A to the TMR increased DMI, OMI, and CPI, and also increased milk yield during wk 3, 6 , and 7 , as did application of $3 \mathrm{~A}$ during wk 6,8 , and 9. Both EFE tended to increase mean FCM yield and mean milk fat yield. No EFE effects were detected on digestibility measures, milk component concentrations and yields of milk protein and lactose, feed efficiency, BW, BW change, BCS, blood glucose, or BUN. Also, EFE treatment did not affect ruminal DM degradation kinetics or ruminal fermentation measures of the TMR. This study confirms our hypothesis that $2 \mathrm{~A}$ and $3 \mathrm{~A}$ can be used to increase the performance of lactating dairy cows fed diets containing $10 \%$ bermudagrass. The study also confirms our second hypothesis that $2 \mathrm{~A}$ would be more effective than $3 \mathrm{~A}$ at increasing the performance of cows based on its greater efficacy at increasing NDFD in our previous in vitro ruminal digestibility studies (Romero et al., 2015c). This study validated the strategic approach to $\mathrm{EFE}$ evaluation that involved using in vitro tests to identify EFE that would increase the performance of lactating dairy cows.

Table 5. Effect of dietary treatment with fibrolytic enzymes on in situ ruminal DM degradation kinetics of a TMR in lactating dairy cows (experiment 2)

\begin{tabular}{|c|c|c|c|c|c|}
\hline Measure & \multicolumn{3}{|c|}{ Treatment $(\mathrm{Trt})^{1}$} & SEM & $\frac{P \text {-value }}{\text { Trt }}$ \\
\hline Potentially degradable DM fraction (\%) & 48.5 & 48.8 & 48.8 & 1.16 & 0.978 \\
\hline Fractional degradation rate of DM $\left(\mathrm{h}^{-1}\right)$ & 0.064 & 0.068 & 0.058 & 0.0048 & 0.414 \\
\hline $\begin{array}{l}\text { Undegradable DM fraction } \\
\text { (\% after } 72 \mathrm{~h} \text { of incubation) }\end{array}$ & 13.6 & 12.7 & 11.9 & 1.16 & 0.616 \\
\hline
\end{tabular}

${ }^{1} \mathrm{CON}=$ control; $2 \mathrm{~A}=$ Xylanase Plus; $3 \mathrm{~A}=75: 25$ mixture of Cellulase Plus and 2A. Xylanase Plus and Cellulase Plus were produced by Dyadic (Jupiter, FL) from nonrecombinant Trichoderma reesei. 
Table 6. Effect of dietary treatment with fibrolytic enzymes on ruminal fermentation measures of lactating dairy cows ${ }^{1}$

\begin{tabular}{|c|c|c|c|c|c|c|c|}
\hline Measure & \multicolumn{3}{|c|}{ Treatment $(\text { Trt })^{1}$} & SEM & \multicolumn{3}{|c|}{$P$-value } \\
\hline $\mathrm{pH}$ & 6.10 & 6.10 & 6.07 & 0.135 & 0.979 & $<0.001$ & 0.250 \\
\hline Total VFA $(\mathrm{m} M)$ & 155.0 & 149.4 & 164.7 & 6.66 & 0.292 & 0.002 & 0.386 \\
\hline Acetate $(\mathrm{A} ; \mathrm{m} M)$ & 87.1 & 81.5 & 88.6 & 2.44 & 0.126 & $<0.001$ & 0.205 \\
\hline Propionate (P: $\mathrm{m} M$ ) & 35.5 & 34.0 & 40.8 & 2.46 & 0.164 & 0.001 & 0.451 \\
\hline Valerate $(\mathrm{m} M)$ & $7.3^{\mathrm{a}}$ & $9.3^{\mathrm{a}}$ & $9.0^{\mathrm{a}}$ & 1.79 & 0.691 & 0.008 & 0.696 \\
\hline $\mathrm{A}: \mathrm{P}$ & 2.6 & 2.5 & 2.3 & 0.11 & 0.212 & $<0.001$ & 0.991 \\
\hline $\mathrm{A}+\mathrm{B}: \mathrm{P}$ & 3.1 & 3.0 & 2.8 & 0.13 & 0.191 & $<0.001$ & 0.991 \\
\hline
\end{tabular}

${ }^{\mathrm{a}}$ Means in the same row with superscripts differed $(P<0.05)$.

${ }^{1} \mathrm{CON}=$ control; $2 \mathrm{~A}=$ Xylanase Plus; $3 \mathrm{~A}=75: 25$ mixture of Cellulase Plus and 2A. Xylanase Plus and Cellulase Plus were produced by Dyadic (Jupiter, FL) from nonrecombinant Trichoderma reesei.

\section{ACKNOWLEDGMENTS}

We gratefully acknowledge the statistical advice of Mihai Giurcanu of the University of Florida-IFAS Statistical Consulting Unit as well as funding for the project by Adisseo France SAS (Antony, France). We acknowledge the outstanding work of visiting scholars, including Bibiana Coy (Universidad Nacional de Colombia - Sede Bogotá, Colombia), Fabiola Martinez da Silva (Universidade Estadual Paulista "Julio de Mesquita Filho"- Câmpus de Botucatu, Brazil), and Diego Garbuio (Universidade Estadual Paulista "Julio de Mesquita Filho"- Câmpus de Jaboticabal, Brazil), and undergraduate interns Illeana Brody, Chelsea Curry, and Kelly Mills (University of Florida, Gainesville).

\section{REFERENCES}

Adesogan, A. T., Z. X. Ma, J. J. Romero, and K. G. Arriola. 2014. Improving cell wall digestion and animal performance with fibrolytic enzymes. J. Anim. Sci. 92:1317-1330.

Allen, M. S. 1996. Physical constraints on voluntary intake of forages by ruminants. J. Anim. Sci. 74:3063-3075.

AOAC International. 2000. Official Methods of Analysis. 17th ed. AOAC Int., Arlington, VA.

Arriola, K. G., S. C. Kim, C. R. Staples, and A. T. Adesogan. 2011. Effect of fibrolytic enzyme application to low- and high-concentrate diets on the performance of lactating dairy cattle. J. Dairy Sci. 94:832-841.

Beauchemin, K. A., D. Colombatto, D. P. Morgavi, and W. Z. Yang. 2003. Use of exogenous fibrolytic enzymes to improve feed utilization by ruminants. J. Anim. Sci. 81:37-47.

Beauchemin, K. A., and L. Holtshausen. 2010. Developments in enzyme usage in ruminants. Pages 206-230 in Enzymes in Farm Animal Nutrition. 2nd ed. M. R. Bedford and G. G. Partridge, ed. CAB International, Wallingford, UK.

Beauchemin, K. A., L. M. Rode, M. Maekawa, D. P. Morgavi, and R. Kampen. 2000. Evaluation of a nonstarch polysaccharidase feed enzyme in dairy cow diets. J. Dairy Sci. 83:543-553.

Bedford, M. R., and G. G. Partridge. 2010. Feed enzymes, the future: Bright hope or regulatory minefield? Pages 304-312 in Enzymes in Farm Animal Nutrition, 2nd ed. M. R. Bedford and G. G. Partridge, ed. CAB International, Wallingford, UK.
Bernard, J. K., J. J. Castro, N. A. Mullis, A. T. Adesogan, J. W. West, and G. Morantes. 2010. Effect of feeding alfalfa hay or Tifton 85 bermudagrass haylage with or without a cellulase enzyme on performance of Holstein cows. J. Dairy Sci. 93:5280-5285.

Cochran, R. C., W. K. Coblentz, and E. S. Vanzant. 2007. Animal methods for evaluating forage quality. Pages 541-552 in Forages: The Science of Grassland Agriculture. R. F. Barnes, C. J. Nelson, K. J. Moore and M. Collins, ed. Blackwell Publishing, Ames, IA.

Colombatto, D., and K. A. Beauchemin. 2003. A proposed methodology to standardize the determination of enzymic activities present in enzyme additives used in ruminant diets. Can. J. Anim. Sci. 83:559-568.

Considine, P. J., and M. P. Coughlan. 1989. Production of carbohydrate-hydrolyzing enzyme blends by solid-state fermentation. Pages 273-281 in Enzyme Systems for Lignocellulose Degradation. M. P. Coughlan, ed. Elsevier Applied Science, New York, NY.

Dean, D. B., C. R. Staples, R. C. Littell, S. C. Kim, and A. T. Adesogan. 2013. Effect of method of adding a fibrolytic enzyme to dairy cow diets on feed intake digestibility, milk production, ruminal fermentation, and blood metabolites. Anim. Nutr. Feed Technol. 13:287-302.

Dhiman, T. R., M. S. Zaman, R. R. Gimenez, J. L. Walters, and R. Treacher. 2002. Performance of dairy cows fed forage treated with fibrolytic enzymes prior to feeding. Anim. Feed Sci. Technol. 101:115-125.

Eun, J. S., and K. A. Beauchemin. 2007. Enhancing in vitro degradation of alfalfa hay and corn silage using feed enzymes. J. Dairy Sci. 90:2839-2851.

Eun, J. S., and K. A. Beauchemin. 2008. Relationship between enzymic activities and in vitro degradation of alfalfa hay and corn silage. Anim. Feed Sci. Technol. 145:53-67.

FAWN. 2013. Florida Automated Weather Network. Accessed Sep. 28, 2013. http://fawn.ifas.ufl.edu.

Gochman, N., and J. M. Schmitz. 1972. Application of a new peroxide indicator reaction to the specific, automated determination of glucose with glucose oxidase. Clin. Chem. 18:943-950.

Hanna, W. W., and L. E. Sollenberger. 2007 Tropical and subtropical grasses. Pages 245-256 in Forages: The Science of Grassland Agriculture. R. F. Barnes, C. J. Nelson, K. J. Moore and M. Collins, ed. Blackwell Publishing, Ames, IA.

Holtshausen, L., Y.-H. Chung, H. Gerardo-Cuervo, M. Oba, and K. A. Beauchemin. 2011. Improved milk production efficiency in early lactation dairy cattle with dietary addition of a developmental fibrolytic enzyme additive. J. Dairy Sci. 94:899-907.

Knowlton, K. F., J. M. McKinney, and C. Cobb. 2002. Effect of a direct-fed fibrolytic enzyme formulation on nutrient intake, partitioning, and excretion in early and late lactation Holstein cows. J. Dairy Sci. 85:3328-3335. 
Krueger, N. A., A. T. Adesogan, C. R. Staples, W. K. Krueger, S. C. Kim, R. C. Littell, and L. E. Sollenberger. 2008. Effect of method of applying fibrolytic enzymes or ammonia to bermudagrass hay on feed intake, digestion, and growth of beef steers. J. Anim. Sci. 86:882-889.

Kung, L. Jr., M. A. Cohen, L. M. Rode, and R. J. Treacher. 2002. The effect of fibrolytic enzymes sprayed onto forages and fed in a total mixed ration to lactating dairy cow. J. Dairy Sci. 85:2396-2402.

Lewis, G. E., W. K. Sanchez, C. W. Hunt, M. A. Guy, G. T. Pritchard, B. I. Swanson, and R. J. Treacher. 1999. Effect of direct-fed fibrolytic enzymes on the lactational performance of dairy cows. J. Dairy Sci. 82:611-617.

Littell, R. C., G. A. Milliken, W. W. Stroup, R. D. Wolfinger, and O. S. Schabenberger. 2006. Analysis of repeated measures. Pages 159-204 in SAS for Mixed Models. SAS Institute Inc., Cary, NC.

Lynch, J. P., D. Prema, J. D. Van Hamme, J. S. Church, and K. A. Beauchemin. 2014. Fiber degradability, chemical composition and conservation characteristics of alfalfa haylage ensiled with exogenous fibrolytic enzymes and a ferulic acid esterase-producing inoculant. Can. J. Anim. Sci. 94:697-704.

Marsh, W. H., B. Fingerhut, and H. Miller. 1965. Automated and manual direct methods for the determination of blood urea. Clin. Chem. 11:624-627.

Martin, T. D., C. A. Brockhoff, J. T. Creed, and EMMC Methods Work Group. 1994. Determination of metals and trace elements in water and wastes by inductively coupled plasma-atomic emission spectrometry. Revision 4.4. US Environmental Protection Agency, Washington, DC.

Meale, S. J., K. A. Beauchemin, A. N. Hristov, A. V. Chaves, and T. A. McAllister. 2014. Opportunities and challenges in using exogenous enzymes to improve ruminant production. J. Anim. Sci. 92:427-442.

Mertens, D. R. 1977. Dietary fiber components: Relationship to the rate and extent of ruminal digestion. Fed. Proc. 36:187-192.

Mertens, D. R. 1987. Predicting intake and digestibility using mathematical models of ruminal function. J. Anim. Sci. 64:1548-1558.

Mouriño, F., R. Akkarawongsa, and P. J. Weimer. 2001. Initial pH as a determinant of cellulose digestion rate by mixed ruminal microorganisms in vitro. J. Dairy Sci. 84:848-859.

Muck, R. E., and J. T. Dickerson. 1988. Storage temperature effects on proteolysis in alfalfa silage. Trans. ASAE 31:1005-1009.

Noel, R. J., and L. G. Hambleton. 1976. Collaborative study of a semiautomated method for determination of crude protein in animal feeds. J. Assoc. Off. Anal. Chem. 59:134-140.

NRC. 2001. Nutrient Requirements of Dairy Cattle. 7th ed. National Academies Press, Washington, DC.

Paloheimo, M., J. Pironen, and J. Vehamaanperä. 2010. Xylanases and cellulases as feed additives. Pages 12-53 in Enzymes in Farm Animal Nutrition. 2nd ed. M Bedford and G. Partridge, ed. CAB International, Wallingford, UK.

Phakachoed, N., W. Suksombat, D. Colombatto, and K. A. Beauchemin. 2013. Use of fibrolytic enzymes additives to enhance in vitro ruminal fermentation of corn silage. Livest. Sci. 157:100-112.

Queiroz, O. C. M., A. T. Adesogan, J. L. P. Daniel, J. J. Romero, J. H. Shin, C. R. Staples, and J. E. P. Santos. 2011. Effects of adding fibrolytic enzymes to diets containing bermudagrass silage harvested at two maturity stages on the performance of lactating Holstein cattle. J. Anim. Sci. 89(E-Suppl. 1):378. (Abstr.)

Romero, J. J., Z. X. Ma, C. F. Gonzalez, and A. T. Adesogan. 2015c. Effect of adding cofactors to exogenous fibrolytic enzymes on preingestive hydrolysis, in vitro digestibility and fermentation of bermudagrass haylage. J. Dairy Sci. 98:4659-4672.

Romero, J. J., Z. X. Ma, E. G. Macias, D. H. Garbuio, and A. T. Adesogan. 2014. Forage type and exogenous fibrolytic enzyme application rate effects on the digestibility of dairy cattle forages. J. Dairy Sci. 97(E-Suppl. 1):1584. (Abstr.)

Romero, J. J., M. A. Zarate, and A. T. Adesogan. 2015b. Effect of the dose of exogenous fibrolytic enzyme preparations on pre-ingestive fiber hydrolysis and in vitro digestibility of bermudagrass haylage. J. Dairy Sci. 98:406-417.

Romero, J. J., M. A. Zarate, K. G. Arriola, C. F. Gonzalez, C. SilvaSanchez, and A. T. Adesogan. 2015a. Screening exogenous fibrolytic enzymes preparations for improved in vitro digestibility of bermudagrass haylage. J. Dairy Sci. 98:2555-2567.

Romero, J. J., M. A. Zarate, O. C. M. Queiroz, J. H. Han, J. H. Shin, C. R. Staples, W. F. Brown, and A. T. Adesogan. 2013. Fibrolytic enzyme and ammonia application effects on the nutritive value, intake, and digestion kinetics of bermudagrass hay in beef cattle. J. Anim. Sci. 91:4345-4356.

Schingoethe, D. J., G. A. Stegeman, and R. J. Treacher. 1999. Response of lactating dairy cows to a cellulase and xylanase enzyme mixture applied to forages at the time of feeding. J. Dairy Sci. 82:996-1003.

Schneider, B. H., and W. P. Flatt. 1975. The indicator method. Page 168 in The Evaluation of Feeds Through Digestibility Experiments. University of Georgia Press, Athens.

Sutton, J. D., R. H. Phipps, D. E. Beever, D. J. Humphries, G. F. Hartnell, J. L. Vicini, and D. L. Hard. 2003. Effect of method of application of a fibrolytic enzyme product on digestive processes and milk production in Holstein-Friesian cows. J. Dairy Sci. 86:546-556.

Van Soest, P. J., J. B. Robertson, and B. A. Lewis. 1991. Methods for dietary fiber, neutral detergent fiber and non-starch polysaccharides in relation to animal nutrition. J. Dairy Sci. 74:3583-3597.

Wang, Y., and T. A. McAllister. 2002. Rumen microbes, enzymes and feed digestion - A review. Asian-australas. J. Anim. Sci. 15:1659 1676.

Wildman, E. E., G. M. Jones, P. R. Wagner, and R. L. Boman. 1982 A dairy cow body condition scoring system and its relation to selected production characteristics. J. Dairy Sci. 65:495-501.

Wood, T. M., and K. M. Bhat. 1988. Methods for measuring cellulase activities. Pages 87-112 in Methods in Enzymology. W. A. Wood, and S. T. Kellogg, ed. Vol. 160. Academic Press. London, UK.

Yang, W. Z., K. A. Beauchemin, and L. M. Rode. 1999. Effects of an enzyme feed additive on extent of digestion and milk production of lactating dairy cows. J. Dairy Sci. 82:391-403.

Yang, W. Z., K. A. Beauchemin, and L. M. Rode. 2000. A comparison of methods of adding fibrolytic enzymes to lactating cow diets. J. Dairy Sci. 83:2512-2520. 